\begin{tabular}{cc|c}
\hline Tar. Bil. Der. & Journal of Agricultural Sciences \\
& $\begin{array}{c}\text { Dergi web sayfası: } \\
\text { www.agri.ankara.edu.tr/dergi }\end{array}$ & Journal homepage: \\
& www.agri.ankara.edu.tr/journal
\end{tabular}

\title{
Determination of Forage Yield Performance of Some Promising Narbon Vetch (Vicia narbonensis L.) Lines under Rainfed Conditions in Southeastern Turkey
}

\author{
Mehmet Salih SAYAR ${ }^{\mathrm{a}}$, Yavuz HAN ${ }^{\mathrm{b}}$ \\ ${ }^{a}$ Dicle University, Bismil Vocational Training High School, Department of Crops and Animal Production, 21500, Bismil, Diyarbakur, TURKEY \\ ${ }^{b}$ GAP International Agricultural Research and Training Center, 21110, Diyarbakır, TURKEY
}

\section{ARTICLE INFO}

Research Article

DOI: 10.1501/Tarimbil_0000001296

Corresponding Author: Mehmet Salih SAYAR, E-mail: msalihsayar@hotmail.com, Tel: +90 (412) 2411000

Received: 03 January 2014, Received in Revised Form: 12 March 2012, Accepted: 14 March 2014

\begin{abstract}
This study was conducted to determine fresh forage yield, dry matter yield, and their affecting components in promising narbon vetch lines (Vicia narbonensis L.) under rainfed conditions in the Southeastern Anatolia region of Turkey. Field trials were performed in the research areas of GAP International Agricultural Research and Training Center (GAP IARTC) in Diyarbakir, Turkey during the 2008-09, 2009-10 and 2010-11 growing seasons with winter sowings. Experiments were established according to randomized blocks design with three replications. Although the genotype $\times$ year interaction for the natural plant height trait was not found to be significant, the interaction was statistically significant $(\mathrm{P}<0.05)$ for the main stem number trait. For the other five traits, including fresh forage and dry matter yields, the genotype $\times$ year interaction was highly statistically significant $(\mathrm{P}<0.01)$. Among growing seasons and genotypes the investigated traits had ranges as follows: fresh forage yield $-19.42-37.95 \mathrm{tha}^{-1}$; dry matter yield $-4.07-7.16 \mathrm{t} \mathrm{ha}^{-1}$; days to $50 \%$ flowering $-142.3-171.0$ days; natural plant height $-63.8-79.3 \mathrm{~cm}$; main stem height $-79.3-133.3 \mathrm{~cm}$; main stem numbers per plant $-1.93-3.40$ stems plant $^{-1}$; and main stem thickness - 33.2-4.97 mm. Correlation analyses indicated that there were highly significant and positive correlation between fresh forage yield and dry matter yield, though the correlation between fresh forage yield and days to $50 \%$ flowering were found as statistically significant and positive $(\mathrm{P}<0.05)$. According to averages over the three study years five promising narbon vetch lines: IFVN 564-Sel 2379, IFVN 565-Sel 2380, IFVN 567-Sel 2382, IFVN 116-Sel 2461, IFVN 562-Sel 2470, were all found more productive than the control cultivar, Tarman-2002, in terms of both fresh forage yield and dry matter yield. Keywords: Narbon vetch (Vicia narbonensis L.); Fresh forage yield; Dry matter yield; Correlation; Genotype $\times$ year interaction
\end{abstract}

\section{Bazı Ümitvar Koca Fiğ (Vicia narbonensis L.) Hatlarının Güneydoğu Anadolu Bölgesi Yağışa Dayalı Koşullarında Ot Verim Performanslarının Belirlenmesi}

\section{ESER BILGISİ}

Araştırma Makalesi

Sorumlu Yazar: Mehmet Salih SAYAR, E-posta: msalihsayar@hotmail.com, Tel: +90 (412) 2411000

Geliş Tarihi: 03 Ocak 2014, Düzeltmelerin Gelişi: 12 Mart 2014, Kabul: 14 Mart 2014 


\section{ÖZET}

Bu çalışma, bazı ümitvar koca fiğ (Vicia narbonensis L.) hatlarının Güneydoğu Anadolu Bölgesi ekolojik koşullarında yeşil ot ve kuru madde verimleri ile bu verimler üzerinde etkili bazı önemli verim unsurlarını saptamak amacıyla yürütülmüştür. Bu amaçla; 2008-09, 2009-10 ve 2010-11 ekim sezonlarında Diyarbakır GAP Uluslararası Tarımsal Araştırma ve Eğitim Merkezi Müdürlüğü deneme arazisinde, tesadüf blokları deneme desenine göre üç tekrarlamalı olarak tarla denemeleri yürütülmüştür. Araştırmada yeşil ot verimi ve kuru madde veriminin de aralarında bulunduğu beş özellik bakımından genotip $\times$ yıl interaksiyonu 0.01 düzeyinde istatistiki olarak önemli bulunurken, ana sap sayısı özelliği bakımından 0.05 düzeyinde önemli bulunmuştur. Doğal bitki boyu özelliği bakımından ise genotip $\times$ yıl interaksiyonu istatistiki olarak önemsiz bulunmuştur. Araştırmada denemenin yürütüldüğü yıllar ve genotipler arasında incelenen özellikler aşağıdaki gibi değişim göstermiştir. Yeşil ot verimi 19.42-37.95 $\mathrm{t} \mathrm{ha}^{-1}$; kuru madde verimi 4.07-7.16 t ha ${ }^{-1} ; \% 50$ çiçeklenme gün sayısı 142.3-171.0 gün; doğal bitki boyu 63.8-79.3 cm; ana sap uzunluğu 79.3-133.3 cm; ana sap sayıs1 1.93-3.40 sap bitki ${ }^{-1}$; ana sap kalınlığ $3.32-4.97 \mathrm{~mm}$. Korelasyon analizi sonucuna göre; yeşil ot verimi ile kuru madde verimi arasında istatistiki olarak çok önemli ve olumlu ilişki belirlenirken $(\mathrm{P}<0.01)$, yeşil ot verimi ile genotiplerin \% 50 çiçeklenme gün sayısı özelliği arasında 0.05 düzeyinde önemli ve olumlu ilişki saptanmıştır. Üç yıllık araştırma ortalamalarına göre; IFVN 564-Sel 2379, IFVN 565-Sel 2380, IFVN 567-Sel 2382, IFVN 116-Sel 2461 ve IFVN 562-Sel 2470 koca fiğ hatlarının yeşil ot verimi ve kuru madde verimi bakımından kontrol çeşidi Tarman-2002 çeşidine göre daha üstün olduğu saptanmıştır.

Anahtar Kelimeler: Koca fiğ (Vicia narbonensis L.); Yeşil ot verimi; Kuru madde verimi; Korelasyon; Genotip $\times$ y1l interaksiyonu

(C) Ankara Üniversitesi Ziraat Fakültesi

\section{Introduction}

The Southeastern Anatolia Region of Turkey, known as Upper Mesopotamia, is located within the 'Fertile Crescent'. According to Lindsey \& Reynold (2003) the region has hosted agricultural activities for $\sim 8000$ years. The region's soils are famous for their fertility and the climatic conditions allow for the cultivation of most forage crop species (Sayar et al 2010). However, the cultivation of forage crops is currently far below the potential level (Yolcu \& Tan 2008). Accordingly, a shortage of quality roughage presents a serious problem to animal husbandry in the region. Therefore, livestock are fed predominantly cereal chaff and straw, which have low nutritional values and are used as filler material to keep livestock from feeling hungry. However, in order to obtain animal products, milk, meat etc., from the livestock in desired levels, they should be fed with quality roughage obtained from forage crop species. According to Yucel et al (2009), to meet the current requirements for quality roughage of the expanding livestock population in Southeastern Anatolia Region of Turkey, it is of great importance to determine suitable forage crop species.
Narbon vetch (Vicia narbonensis L.), which is resistant to cold and drought, is an annual legume species (Açıköz 2001; Fırıncıŏlu et al 2012). Narbon vetch has been grown as a forage crop species for many years in the Southeastern Anatolia region of Turkey, and the species is readily found among native flora of the region (Sayar 2011). Larbi et al (2010) reported that due to its high potential seed yield, $V$. narbonensis is generally grown for its grain in livestock feed. The species is also of great importance in crop rotation systems, either as pure stands or in a mixture with cereals for fresh forage or hay to provide high quality livestock feed (Altınok 2002; Altınok \& Hakyemez 2002; Iptaş \& Karadağ 2009; Nizam et al 2011). Furthermore, narbon vetch is a valuable green manure plant due to high green biomass production, and as a legume, its ability to fix large amounts of nitrogen to the soil (Albayrak et al 2004a; Albayrak et al 2004b; Avcıŏlu et al 2009; Fırıncıoğlu et al 2012).

The objective of this study was to determine the forage yield and affecting traits of some promising narbon vetch lines in rainfed areas of Southeastern Anatolia, Turkey. 


\section{Material and Methods}

This study was conducted for three consecutive growing seasons (2008-2009, 2009-2010 and 2010-2011) in the experimental areas of the GAP International Agricultural Research and Training Centre (GAP IARTC), Diyarbakır, Turkey (37056'41.0'N , 40¹5'16.8' E and altitude $607 \mathrm{~m}$ ).

The study materials consisted of six promising lines and one control cultivar. The genetic materials and their origins are listed in Table 1. The promising lines were provided from International Center for Agricultural Research in Dry Areas, Aleppo, Syria (ICARDA). The narbon vetch lines we used were previously determined to be promising as the result of trials previously conducted at the GAP International Agricultural Research and Training Centre, Diyarbakır, Turkey. In addition Tarman-2002-which was supplied by its breeder's institution, the Central Research Institute for Field Crops, Ankara, Turkey-was used as a control cultivar.

The research fields were flat or near flat with very little erosion, and the soil layer had a deep or medium deep profile. According to the soil analysis, the experimental area soils had a clay loam structure, and were red-brown in color. Moreover, the soils were rich in terms of calcium (12.54\%) and potassium $\left(480 \mathrm{~kg} \mathrm{ha}^{-1} \mathrm{~K}_{2} \mathrm{O}\right)$ contents, whereas organic matter $(1.60 \%)$ and phosphorus $(28.5 \mathrm{~kg}$ ha ${ }^{-1} \mathrm{P}_{2} \mathrm{O}_{5)}$ contents were relatively low. Also, due to the high limestone content, the $\mathrm{pH}$ status of the soils was slightly alkaline (pH: 7.67).

The Southeastern Anatolia Region is one of Turkey's seven census-defined geographical regions, and is characterized by a continental climate. In this region, summers are dry and hot, whereas winters are cool and rainy. Rainfall in the region is variable both within and among years. The long-term annual average (1975-2011) total precipitation is 479.8 $\mathrm{mm}$, approximately three-quarters of which (75$80 \%$ ) falls from November to May. The region's forage and seed yields obtained from annual legume crops depend greatly on the spring rainfall. Monthly average temperature, humidity and total precipitation records during the study years, and the long-term averages, are summarized in Table 2 (TMF 2011).

The experiments were conducted under rainfed conditions according to a randomized complete block design with three replications. Each plot consisted of six rows $5 \mathrm{~m}$ in length, and rows were spaced $20 \mathrm{~cm}$ apart. Diammonium phosphate fertilizer (DAP 18-46-00) (150 kg ha$\left.{ }^{1}\right)$ was applied in the experimental plots with the sowings. Weeds appearing in the experimental area were controlled by hand. The seeding rate was 100 seeds $\mathrm{m}^{-2}$ (Açıkgöz 2001). The sowings were made in well-annealed soil using an experimental drill. The sowing dates for first, second and third growing seasons were on November 14, 2008, November 20, 2009 and November 11, 2010,

Table 1- The used genetic materials in the study and their ICARDA registration chart

Çizelge 1-Çalışmada kullanılan genetik materyal ve ICARDA kayıt çizelgeleri

\begin{tabular}{clcc}
\hline No & The genotypes & Origin & FAO status \\
\hline 1 & IFVN 564 Sel 2379 & Lebanon & D (Designated) \\
2 & IFVN 565 Sel 2380 & Lebanon & D \\
3 & IFVN 575 Sel 2389 & Lebanon & D \\
4 & IFVN 567 Sel 2382 & Lebanon & D \\
5 & IFVN 116 Sel 2461 & Turkey & D \\
6 & IFVN 562 Sel 2470 & Lebanon & D \\
7 & Tarman-2002 (Control cultivar) & Turkey & \\
\hline
\end{tabular}


Table 2- Long-term average (1975-2012) and during the three growing seasons monthly mean temperature, relative humidity and total precipitation at Diyarbakır province (TMF 2011)

Çizelge 2- Diyarbaklr ilinde denemelerin yürütüldüğ̈̈ ̈̈ç yıla ait ayllk ortalama sıcaklı, ortalama nisbi nem değerleriyle aylık toplam yă̆ı̧̧ miktarı ve uzun ylllar ortalaması (1975-2012) (TMF 2011)

\begin{tabular}{|c|c|c|c|c|c|c|c|c|c|c|c|}
\hline & Sept. & Oct. & Nov. & Dec. & Jan. & Feb. & March & Apr. & May & June & \\
\hline Years & \multicolumn{10}{|c|}{ Mean air temperature (C) (Monthly) } & Mean \\
\hline 2008-09 & 24.1 & 16.8 & 10.1 & 2.2 & 1.4 & 5.6 & 7.9 & 11.8 & 18.2 & 25.9 & 12.4 \\
\hline 2009-10 & 22.9 & 18.5 & 9.8 & 7.1 & 5.4 & 6.6 & 11.1 & 14.2 & 20.4 & 27.2 & 14.3 \\
\hline 2010-11 & 27.0 & 18.1 & 11.1 & 6.5 & 3.5 & 4.7 & 9.0 & 13.0 & 17.7 & 25.5 & 13.6 \\
\hline \multirow[t]{2}{*}{$1975-2012$} & 24.7 & 17.0 & 8.9 & 3.8 & 1.7 & 3.5 & 8.2 & 13.7 & 19.1 & 26.3 & 12.7 \\
\hline & \multicolumn{10}{|c|}{ Mean relative humidity (\%) (Monthly) } & Mean \\
\hline 2008-09 & 26.3 & 50.2 & 50.6 & 57.3 & 73.3 & 82.5 & 73.8 & 71.3 & 51.8 & 32.2 & 56.9 \\
\hline 2009-10 & 33.0 & 42.0 & 70.6 & 83.5 & 80.9 & 79.9 & 66.6 & 60.4 & 49.3 & 29.1 & 59.5 \\
\hline 2010-11 & 27.4 & 56.0 & 41.1 & 68.9 & 73.4 & 69.5 & 56.4 & 75.7 & 67.6 & 38.0 & 57.4 \\
\hline \multirow[t]{2}{*}{$1975-2012$} & 30.9 & 48.0 & 67.1 & 76.7 & 77.1 & 72.8 & 65.6 & 63.2 & 56.3 & 35.9 & 59.4 \\
\hline & \multicolumn{10}{|c|}{ Total precipitation (mm) (Monthly) } & Total \\
\hline 2008-09 & 68.2 & 59.2 & 50.5 & 52.2 & 12.4 & 70.0 & 63.9 & 43.7 & 9.1 & 25.8 & 455.0 \\
\hline 2009-10 & 25.2 & 62.4 & 55.6 & 87.2 & 113.4 & 40.2 & 68.7 & 22.4 & 31.6 & 11.2 & 517.9 \\
\hline 2010-11 & 0.4 & 63.4 & 2.0 & 48.0 & 40.0 & 49.9 & 46.6 & 209.0 & 80.1 & 13.6 & 553.0 \\
\hline $1975-2012$ & 4.7 & 34.6 & 53.3 & 70.7 & 62.3 & 72.1 & 68.2 & 64.6 & 40.2 & 9.1 & 479.8 \\
\hline
\end{tabular}

respectively. In the experiments; after a halfmeter at the beginning and end of each plot was neglected to account for edge effects, half of each plot was harvested separately in May to calculate fresh forage yield, and the fresh forages weighed as soon as possible without losing weight. Then, the found fresh forage yields converted acre. For determining dry matter yield $500 \mathrm{~g}$ fresh forage sample were taken from each plot, then, the forage samples were dried $48 \mathrm{~h}$ in an oven at $70{ }^{\circ} \mathrm{C}$. Fresh forage yield, dry matter yield and the other investigated traits were determined according to the technical instructions for leguminous forage crops published by the Seed Registration and Certification Centre, Ankara, Turkey (TIRTAFLS 2001).

All statistical analyses of data were performed using the JMP 5.0.1 statistical software package (SAS Institute 2002), and the differences between means were compared using the least significant difference (LSD) test at the 0.05 probability level (Steel \& Torrie 1960).

\section{Results and Discussion}

The combined variance analysis over the 3 years showed that years, genotypes and genotype $\times$ year interaction were highly significant $(\mathrm{P}<0.01)$ both for fresh forage yield and dry matter yield. Fresh forage yield among the years showed great differences. The highest fresh forage yield, of $34.45 \mathrm{tha}^{-1}$, was obtained in the 2010-11 growing season. The other 2 years' fresh forage yields were determined as $28.70 \mathrm{tha}^{-1}$ and 23.89 $\mathrm{t} \mathrm{ha}^{-1}$ for the 2009-10 and 2008-2009 growing seasons, respectively (Table 3 ). The high fresh forage yield in the 2010-11 growing season was due almost exclusively to the amount of spring rainfall, which was much higher in April in this growing season than during the other two growing seasons (Tables 2 and 3). Similarly, many researchers have reported that the yields of annual forage legumes greatly depend on spring rains in rainfed conditions (Gramsh 1982; Açıkgöz et al 1986; Karadağ \& Büyükburç 2004; Sayar et al 2011). In contrast, the dry matter yields of narbon vetch obtained in the 2009-10 and 201011 growing seasons were found to be higher than in 2008-09 growing season. 
Table 3- Fresh forage and dry matter yields of the narbon vetch (Vicia narbonensis L.) genotypes Çizelge 3- Koca fĭg (Vicia narbonensis L.) genotiplerinde yeşil ot ve kuru madde verimleri

\begin{tabular}{|c|c|c|c|c|c|c|c|c|c|}
\hline \multirow{3}{*}{$\begin{array}{l}\text { Genotypes } \\
\text { IFVN 564-Sel } 2379\end{array}$} & \multicolumn{4}{|c|}{ Fresh forage yield $\left(t h^{-1}\right)$} & \multicolumn{5}{|c|}{ Dry matter yield $\left(t h a^{-1}\right)$} \\
\hline & \multirow{2}{*}{$\frac{2008-09}{26.52 \mathrm{e}^{+}}$} & $2009-10$ & $2010-11$ & Mean & $2008-09$ & \multicolumn{2}{|c|}{$2009-10$} & $2010-11$ & Mean \\
\hline & & $32.87 \quad b-c$ & $34.24 \mathrm{~b}$ & $31.21 \mathrm{a}$ & $5.84 \mathrm{c}-\mathrm{f}$ & 6.69 & a-c & $5.84 \mathrm{c}-\mathrm{f}$ & $6.12 \mathrm{a}$ \\
\hline IFVN 565-Sel 2380 & $27.13 \mathrm{~d}-\mathrm{e}$ & $33.95 \mathrm{~b}$ & $32.71 \mathrm{~b}-\mathrm{c}$ & $31.26 \mathrm{a}$ & $5.94 \mathrm{c}-\mathrm{f}$ & 6.89 & $a-b$ & $5.95 \mathrm{c}-\mathrm{f}$ & $6.26 \mathrm{a}$ \\
\hline IFVN 575-Sel 2389 & $20.99 \mathrm{f}-1$ & 20.03 h-1 & $30.31 \mathrm{c}-\mathrm{d}$ & $23.78 \mathrm{~d}$ & $4.85 \mathrm{~g}-1$ & 4.07 & 1 & $5.75 \mathrm{~d}-\mathrm{f}$ & $4.89 \mathrm{~b}$ \\
\hline IFVN 567-Sel 2382 & 24.34 e-f & $33.65 \mathrm{~b}-\mathrm{c}$ & $35.66 \mathrm{a}-\mathrm{b}$ & $31.21 \mathrm{a}$ & $5.58 \mathrm{e}-\mathrm{g}$ & 7.16 & $\mathrm{a}$ & $6.26 \mathrm{~b}-\mathrm{e}$ & $6.33 \mathrm{a}$ \\
\hline IFVN 116-Sel 2461 & $24.23 \mathrm{e}-\mathrm{g}$ & $30.52 \mathrm{c}$ & $32.63 \mathrm{~b}-\mathrm{c}$ & $29.12 \mathrm{~b}$ & $5.85 \mathrm{c}-\mathrm{f}$ & 6.83 & $a-b$ & $5.34 \mathrm{f}-\mathrm{h}$ & $6.00 \mathrm{a}$ \\
\hline IFVN 562-Sel 2470 & $23.14 \mathrm{f}-\mathrm{h}$ & $30.46 \mathrm{c}-\mathrm{d}$ & 37.66 a & $30.42 a-b$ & $5.35 \mathrm{f}-\mathrm{h}$ & 6.45 & $a-d$ & $5.95 \mathrm{c}-\mathrm{f}$ & $5.92 \mathrm{a}$ \\
\hline TARMAN-2002 & $20.92 \mathrm{~g}-1$ & $19.42 \quad 1$ & $37.95 \mathrm{a}$ & $26.10 \mathrm{c}$ & $4.52 \mathrm{~h}-1$ & 4.20 & 1 & 6.31 a-e & $5.01 \mathrm{~b}$ \\
\hline Mean & $23.89 \mathrm{c}$ & $28.70 \mathrm{~b}$ & $34.45 \mathrm{a}$ & & $5.42 \mathrm{~b}$ & 6.04 & $\mathrm{a}$ & $5.91 \mathrm{a}$ & \\
\hline CV $(\%)$ & \multicolumn{4}{|c|}{9.94} & \multicolumn{5}{|c|}{10.27} \\
\hline \multicolumn{10}{|l|}{$\operatorname{LSD}(0.05)$} \\
\hline Year & \multicolumn{4}{|c|}{$1.28 * *$} & \multicolumn{5}{|c|}{$0.32 * *$} \\
\hline Genotype & \multicolumn{4}{|c|}{$1.95 * *$} & \multicolumn{5}{|c|}{$0.51 * *$} \\
\hline Genotype $\times$ year & \multicolumn{4}{|c|}{$3.37 * *$} & \multicolumn{5}{|c|}{$0.87 * *$} \\
\hline
\end{tabular}

${ }^{+}$, means with different letters in the same column are significantly different $(\mathrm{P}<0.05)$; significant at $*, \mathrm{P} \leq 0.05 ;{ }^{* *}, \mathrm{P} \leq 0.01 ; \mathrm{ns}$, nonsignificant

Meanwhile, a very important point worth considering is that although the fresh forage yield in the 2010-11 growing season was found to be significantly higher than in 2009-10 growing season, the dry matter yield in 2009-10 was higher than the 2010-11 dry matter yield. This likely stemmed from the higher temperatures and lower rainfall in the spring of the 2009-10 growing season (Table 2). The higher temperatures and the lower rainfall in the spring month of 2009-10 likely caused the increased dry matter content in the fresh forage.

When the genotype $\times$ year interaction for fresh forage yield and dry matter yield were examined (Table 3), the highest fresh forage yield was obtained from the Tarman-2002 cultivar and the IFVN 562-Sel 2470, the IFVN 567-Sel 2382 lines in the 2010-11 growing season, while the lowest fresh forage yield was recorded from Tarman-2002 in the 2009-10 growing season. However, the highest dry matter yields were obtained from IFVN 565-Sel 2380, IFVN 116-Sel 2461, IFVN 564-Sel 2379, and IFVN 562-Sel 2470 lines in the 2009-10 growing season and in the Tarman-2002 cultivar in the 2010-11 growing season. The lowest dry matter yield was recorded for the IFVN 575-Sel 2389 line and Tarman-2002 cultivar in the 2009-10 growing season. It is important to note that even though fresh forage and dry matter yields of the Tarman-2002 cultivar were found quite high in the 2010-11 growing season, the performance of the cultivar was the worst in the 2009-10 growing season. This result indicated that the Tarman-2002 cultivar showed a good adaptability in spring rainy years, while its fresh forage and dry matter yields were very low in years that had higher temperatures and lower spring rains. However, plant breeders and farmers prefer stable cultivars that can provide at least average yields in the unsuitable conditions. According to three-year averages; five promising narbon vetch lines: IFVN 564-Sel 2379, IFVN 565-Sel 2380, IFVN 567-Sel 2382, IFVN 116-Sel 2461, IFVN 562-Sel 2470, were found more productive than the control cultivar, Tarman-2002, in terms of both fresh forage yield and dry matter yield (Table 3 ).

Previous studies using narbon vetch genotypes under various ecological conditions reported that the fresh forage yield ranged between $24.88 \mathrm{t} \mathrm{ha}^{-1}$ and $38.06 \mathrm{t} \mathrm{ha}^{-1}$, while dry matter yield varied between $5.44 \mathrm{t} \mathrm{ha}^{-1}$ and $7.37 \mathrm{t} \mathrm{ha}^{-1}$ (Büyükburç et al 1994; Anlarsal 1996; Cecen et al 2005; Y1lmaz 
Table 4- Days to $50 \%$ flowering and natural plant heights of the narbon vetch (Vicia narbonensis L.) genotypes

Çizelge 4- Koca fĭg (Vicia narbonensis L.) genotiplerinde \% 50 çiçeklenme gün sayısı ve doğal bitki boyu değerleri

\begin{tabular}{|c|c|c|c|c|c|c|c|c|c|c|}
\hline \multirow[b]{2}{*}{ Genotypes } & \multicolumn{6}{|c|}{ Days to $50 \%$ flowering (days) } & \multicolumn{4}{|c|}{ Natural plant height $(\mathrm{cm})$} \\
\hline & $2008-09$ & 2009 & & $2010-1$ & Mea & & $2008-09$ & $2009-10$ & $2010-11$ & Mean \\
\hline IFVN 564-Sel 2379 & $161.3 \mathrm{~d}-\mathrm{e}^{+}$ & 142.3 & 1 & 168.3 & 157.3 & $\mathrm{c}$ & 79.3 & 64.4 & 70.6 & 71.4 \\
\hline IFVN 565-Sel 2380 & $161.0 \mathrm{~d}-\mathrm{e}$ & 144.7 & g-h & 168.7 & 158.1 & $\mathrm{~b}$ & 75.7 & 66.2 & 66.5 & 69.4 \\
\hline IFVN 575-Sel 2389 & $162.0 \mathrm{~d}$ & 144.0 & $\mathrm{~h}$ & 168.3 & 158.1 & $\mathrm{~b}$ & 79.0 & 68.0 & 73.4 & 73.5 \\
\hline IFVN 567-Sel 2382 & $163.3 \mathrm{c}$ & 145.3 & $f-g$ & 168.3 & 159.0 & $\mathrm{a}$ & 77.3 & 71.9 & 68.9 & 72.7 \\
\hline IFVN 116-Sel 2461 & 161.7 d-e & 146.0 & $\mathrm{f}$ & 169.0 & 158.9 & $\mathrm{a}$ & 75.7 & 72.2 & 73.5 & 73.8 \\
\hline IFVN 562-Sel 2470 & $161.7 \mathrm{~d}-\mathrm{e}$ & 144.3 & g-h & 169.0 & 158.3 & $a-b$ & 74.0 & 66.0 & 72.9 & 70.9 \\
\hline TARMAN-2002 & $160.7 \mathrm{e}$ & 145.3 & $f-g$ & 171.0 & 159.0 & $\mathrm{a}$ & 72.0 & 63.8 & 73.7 & 69.8 \\
\hline Mean & $161.7 \mathrm{~b}$ & 144.6 & $\mathrm{c}$ & 169.0 & $\mathrm{a}$ & & $76.1 \mathrm{a}$ & $67.5 \mathrm{c}$ & $71.4 \mathrm{~b}$ & \\
\hline CV (\%) & \multicolumn{6}{|c|}{0.44} & \multicolumn{4}{|c|}{6.26} \\
\hline \multicolumn{11}{|l|}{$\operatorname{LSD}(0.05)$} \\
\hline Year & \multicolumn{6}{|c|}{$0.45^{* *}$} & \multicolumn{4}{|c|}{$2.82^{* * *}$} \\
\hline Genotype & \multicolumn{6}{|c|}{$0.69 * *$} & \multicolumn{4}{|c|}{ ns } \\
\hline Genotype $\times$ year & \multicolumn{6}{|c|}{$1.19 * *$} & \multicolumn{4}{|c|}{ ns } \\
\hline
\end{tabular}

${ }^{+}$, means with different letters in the same column are significantly different $(\mathrm{P}<0.05)$; significant at *, $\mathrm{P} \leq 0.05 ;{ }^{* *}, \mathrm{P} \leq 0.01 ; \mathrm{ns}$, nonsignificant

2008; Rahmeti et al 2012). These findings confirm our results, determined in the study relating fresh forage and dry matter yields. On the other hand, data determining dry matter yields in narbon vetch genotypes determined by Berger et al (2002), Turk et al (2007) and Nizam et al (2011) were found to be lower than our data. This difference likely arose from differences among the genotypes used and the environmental conditions under which investigations were conducted.

In annual forage legume species, earlier flowering genotypes are of great importance in terms of crop rotation systems of the Southeastern Anatolia Region, since earlier flowering genotypes not only provide more time to fill their pods before the beginning of hot and dry weather, but also allow sufficient time for the crops that follow. We found statistically highly significant $(\mathrm{P}<0.01)$ differences among the growing seasons (years) in terms of days to reach $50 \%$ flowering in narbon vetch genotypes (Table 4). Days to reach 50\% flowering in the 200910 growing season were significantly fewer than in the other 2 years. The reason for this is likely that rainfall amount, temperature and humidity in the winter months and March were higher than in either the 2008-09 or 2010-11 growing seasons, and the long years averages (Table 2). Due to the favorable climatic conditions in winter months in the 2009-10 growing season, narbon vetch genotypes maintained their growth during the winter months, and they finished their vegetation stage and reached their flowering period earlier in the growing season.

As seen in Table 4, genotypes and the genotype $\times$ year interaction were highly significant $(\mathrm{P}<0.01)$, and the time to reach $50 \%$ flowering time varied among the genotypes and years from 142.3 days to 171.0 days. The earliest $50 \%$ flowering time was recorded for the IFVN 564-Sel 2379 line, whereas the latest flowering time occurred in the Tarman-2002 control cultivar. According to means of the 3 years, the IFVN 564-Sel 2379 line was found to be the genotype with the earliest flowering time. Cecen et al (2005), found that 154 days were required to reach $50 \%$ flowering in narbon vetch, which is consistent with our findings, while Sabanc1 et al (1998) found that a shorter time was required (118-132 days) in Izmir conditions, and Yilmaz (2008) reported a shorter time still (114.6126.4 days) in Hatay conditions. Differences among 
ecological environments under which the previous studies were conducted, and the use of different genotypes, could be the cause of the differences among the previous studies and our findings of the days to reach $50 \%$ flowering. In fact, for nearly all of the field crops, the times to flowering in Izmir and Hatay ecological conditions, which had a Mediterranean climate, were lower than that in Diyarbakir ecological conditions, which had a continental climate.

ANOVA indicated significant differences among growing years, but the differences among the means of genotypes and the genotype $\times$ year interaction were non-significant for natural plant height (Table 4). The non-significance of the genotype $\times$ year interaction indicated that the ranking of narbon vetch genotypes in terms of natural plant height was not significantly affected by changing the years. Buyukburc \& Iptas (2001) reported that although the plant height is a genotypic feature in narbon vetch, this feature is greatly affected by the spring rains. That is, in a year with a relatively high amount of spring precipitation, plant height is also relatively higher. In our study, the greatest natural plant height was in the 2008-09 growing season $(76.1 \mathrm{~cm})$ and the least was in the 2009-10 growing season $(67.5 \mathrm{~cm})$ (Table 4). Our results are consistent with previous reports on natural plant height in narbon vetch reported by Iptaş \& Karadağ (2009) and Nizam et al (2011) of 49.4-74.3 $\mathrm{cm}$ and $43.02-78.85 \mathrm{~cm}$, respectively.

Main stem height in annual legume forage species is more important than natural plant height. Due to lodging, legume forage crop plants often fall to the ground. Therefore, even though a genotype may sometimes have a taller main stem height, it can have a lower natural plant height owing to the lodging. In general the difference between a main stem height and natural plant height account for the lodging degree of the genotype.

Variance analysis of main stem height data indicated that differences among years, genotypes, and genotype $\times$ year interaction were highly significant $(\mathrm{P}<0.01)$ for the trait. The lowest main stem height was recorded in the 2009-10 growing season, and the highest main stem height was recorded in 2008-09 growing season (Table 5). The factors affecting natural plant height among the years mentioned above are also valid for main stem height. In fact, the rankings of the growing seasons in terms of natural plant height and main stem height were identical (Table 4, Table 5). When the genotype $\times$ year interaction was examined for main stem height (Table 5), it was found that the interaction was reached with the highest main stem height in the 2008-09 growing season with IFVN 116-Sel 2461, IFVN 567-Sel 2382, and IFVN 575-Sel 2389 lines, with heights of 133.3, 132.0 and $130.3 \mathrm{~cm}$, respectively. In contrast, the lowest main stem height was determined in IFVN 575-Sel $2389(79.3 \mathrm{~cm})$ for the 2009-10 growing season. These findings indicate that the line of IFVN 575-Sel 2389 did not show a coherent pattern in terms of main stem height, but that this genotype performed well in terms of main stem height in the 2008-09 growing season when mean temperatures were lower than in the other two years (Table 2 and Table 5).

For main stem numbers per plant in the narbon vetch lines the interactions among growing years and among the genotypes were found highly significant at 0.01 level, although the second order interaction of year $\times$ genotype was significant at the 0.05 level. The average main stem number in the 2008-09, 2009-10 and 2010-11 growing seasons were 2.19, 3.08 and 2.66 stems plant $^{-1}$, respectively. According to averages over the 3 years the highest main stem numbers were found in IFVN 562-Sel 2470 (2.91 stems plant $\left.^{-1}\right)$, while the lowest were recorded in IFVN 564-Sel 2379 (2.36 stems plant $\left.{ }^{-1}\right)$ (Table 5).

Additionally, among the years and genotypes, the main stem numbers for different genotypes varied from 1.93 stems plant $^{-1}$ to 3.40 stems plant $^{-1}$. Our main stem number findings are consistent with previous reports of the main stem number per plant in narbon vetch (İptaş et al 1996; Sabanc1 et al 1996; Büyükburç \&İptaş, 2001; Uzunmehmetoğlu \& Kendir 2006; Nizam et al 2011).

Main stem thickness in annual forage species has both positive and negative aspects. On the one hand, a genotype with a higher stem thickness it is more resistant to lodging and laying, while on the other hand a higher stem thickness causes an increased leaf-to- stem ratio in the forages. This decreases the 
Table 5- Main stem height and main stem numbers of the narbon vetch (Vicia narbonensis L.) genotypes Çizelge 5- Koca fĭg (Vicia narbonensis L.) genotiplerinde ana sap uzunluğu ve ana sap sayısı değerleri

\begin{tabular}{|c|c|c|c|c|c|c|c|c|}
\hline \multirow[b]{2}{*}{ Genotypes } & \multicolumn{4}{|c|}{ Main stem height $(\mathrm{cm})$} & \multicolumn{4}{|c|}{ Main stem numbers per plant } \\
\hline & $2008-09$ & $2009-10$ & $2010-11$ & Mean & $2008-09$ & $2009-10$ & $2010-11$ & Mean \\
\hline IFVN 564-Sel 2379 & $116.7 \mathrm{~d}-\mathrm{f}^{+}$ & $92.3 \mathrm{~g}-1$ & $111.2 \mathrm{e}-\mathrm{f}$ & $106.7 \mathrm{a}-\mathrm{b}$ & $2.00 \mathrm{f}-\mathrm{g}$ & $2.53 \mathrm{~d}-\mathrm{e}$ & $2.53 \mathrm{~d}-\mathrm{e}$ & $2.36 \mathrm{c}$ \\
\hline IFVN 565-Sel 2380 & $122.7 \mathrm{~b}-\mathrm{d}$ & $93.3 \mathrm{~g}-\mathrm{h}$ & $116.7 \mathrm{~d}-\mathrm{f}$ & $110.9 \mathrm{a}$ & $1.93 \mathrm{~g}$ & $3.13 \mathrm{a}-\mathrm{b}$ & $3.00 \mathrm{~b}-\mathrm{c}$ & $2.69 \mathrm{~b}$ \\
\hline IFVN 575-Sel 2389 & $130.3 \mathrm{a}-\mathrm{c}$ & 79.31 & $82.1 \mathrm{j}-1$ & $97.3 \mathrm{c}$ & $2.27 \mathrm{e}-\mathrm{g}$ & $3.20 \mathrm{a}-\mathrm{b}$ & $2.33 \mathrm{e}-\mathrm{f}$ & $2.60 \mathrm{~b}$ \\
\hline IFVN 567-Sel 2382 & $132.0 \mathrm{a}-\mathrm{b}$ & $82.51-1$ & $97.4 \mathrm{G}$ & $104.0 \mathrm{~b}$ & $2.33 \mathrm{e}-\mathrm{f}$ & $3.13 \mathrm{a}-\mathrm{b}$ & $2.53 \mathrm{~d}-\mathrm{e}$ & $2.67 \mathrm{~b}$ \\
\hline IFVN 116-Sel 2461 & $133.3 \mathrm{a}$ & $89.5 \mathrm{~g}-\mathrm{k}$ & $97.5 \mathrm{G}$ & $106.8 \mathrm{a}-\mathrm{b}$ & $2.33 \mathrm{e}-\mathrm{f}$ & $3.07 \mathrm{a}-\mathrm{c}$ & $2.73 \mathrm{c}-\mathrm{d}$ & $2.71 \mathrm{a}-\mathrm{b}$ \\
\hline IFVN 562-Sel 2470 & $109.0 \mathrm{f}$ & $85.1 \mathrm{~h}-1$ & $91.0 \mathrm{~g}-\mathrm{j}$ & $95.0 \mathrm{c}$ & $2.27 \mathrm{e}-\mathrm{g}$ & $3.40 \mathrm{a}$ & $3.07 \mathrm{a}-\mathrm{c}$ & $2.91 \mathrm{a}$ \\
\hline TARMAN-2002 & $121.0 \mathrm{c}-\mathrm{e}$ & $80.0 \mathrm{k}-1$ & $115.0 \mathrm{~d}-\mathrm{f}$ & $105.3 \mathrm{a}-\mathrm{b}$ & $2.20 \mathrm{e}-\mathrm{g}$ & $3.07 \mathrm{a}-\mathrm{c}$ & $2.40 \mathrm{~d}-\mathrm{e}$ & $2.56 \mathrm{~b}-\mathrm{c}$ \\
\hline Mean & $123.6 \mathrm{a}$ & $86.0 \mathrm{c}$ & $101.6 \mathrm{~B}$ & & $2.19 \mathrm{c}$ & $3.08 \mathrm{a}$ & $2.66 \mathrm{~b}$ & \\
\hline CV (\%) & \multicolumn{4}{|c|}{7.68} & \multicolumn{4}{|c|}{6.71} \\
\hline \multicolumn{9}{|l|}{$\operatorname{LSD}(0.05)$} \\
\hline Year & \multicolumn{4}{|c|}{$3.84 * *$} & \multicolumn{4}{|c|}{$0.14 * *$} \\
\hline Genotype & \multicolumn{4}{|c|}{$5.85 * *$} & \multicolumn{4}{|c|}{$0.22 * *$} \\
\hline Genotype $\times$ year & \multicolumn{4}{|c|}{$10.15 * *$} & \multicolumn{4}{|c|}{$0.39 *$} \\
\hline
\end{tabular}

Table 6- Main stem thickness values of the narbon vetch (Vicia narbonensis L.) genotypes

Çizelge 6- Koca fĭ̆ (Vicia narbonensis L.) genotiplerinde ana sap kalınlığı değerleri

\begin{tabular}{|c|c|c|c|c|}
\hline \multirow[b]{2}{*}{ Genotypes } & \multicolumn{4}{|c|}{ Main stem thickness (mm) } \\
\hline & $2008-09$ & $2009-10$ & $2010-11$ & \multirow{2}{*}{$\frac{\text { Mean }}{4.00}$} \\
\hline IFVN 564-Sel 2379 & $3.69 \mathrm{~d}-\mathrm{h}$ & $4.14 \mathrm{~b}-\mathrm{d}$ & $4.16 \mathrm{~b}-\mathrm{d}$ & \\
\hline IFVN 565-Sel 2380 & $3.56 \mathrm{e}-\mathrm{h}$ & $3.89 \mathrm{c}-\mathrm{g}$ & $3.93 \mathrm{c}-\mathrm{g}$ & 3.79 \\
\hline IFVN 575-Sel 2389 & $3.32 \mathrm{~h}$ & $4.33 \mathrm{~b}-\mathrm{c}$ & $3.98 \mathrm{~b}-\mathrm{g}$ & 3.88 \\
\hline IFVN 567-Sel 2382 & $3.70 \mathrm{~d}-\mathrm{h}$ & $4.52 \mathrm{a}-\mathrm{b}$ & $4.20 \mathrm{~b}-\mathrm{d}$ & 4.14 \\
\hline IFVN 116-Sel 2461 & $3.55 \mathrm{e}-\mathrm{h}$ & $4.09 \mathrm{~b}-\mathrm{e}$ & $3.80 \mathrm{c}-\mathrm{h}$ & 3.81 \\
\hline IFVN 562-Sel 2470 & $3.51 \mathrm{~g}-\mathrm{h}$ & $4.16 \mathrm{~b}-\mathrm{d}$ & $4.07 \mathrm{~b}-\mathrm{f}$ & 3.91 \\
\hline TARMAN-2002 & $3.49 \mathrm{~g}-\mathrm{h}$ & $4.97 \mathrm{a}$ & $3.53 \mathrm{f}-\mathrm{h}$ & 4.00 \\
\hline Mean & $3.55 \mathrm{c}$ & $4.30 \mathrm{a}$ & $3.95 \mathrm{~b}$ & \\
\hline $\mathrm{CV}(\%)$ & & 6.3 & & \\
\hline \multicolumn{5}{|l|}{ LSD $(0.05)$} \\
\hline Year & \multicolumn{4}{|c|}{$0.22 * *$} \\
\hline Genotype & \multirow{2}{*}{\multicolumn{4}{|c|}{$\begin{array}{c}\mathrm{ns} \\
0.55^{* *}\end{array}$}} \\
\hline Genotype $\times$ year & & & & \\
\hline
\end{tabular}

digestibility and protein content of the forage, and leads to a resultant decrease in forage quality (Ball 2001; Tan et al 2013). In this study, highly significant $(\mathrm{P}<0.01)$ differences were found among growing years in terms of the main stem thickness traits of narbon vetch genotypes, whereas differences among the means of genotypes were found to be not significant for the trait. Also, a genotype $\times$ year interaction was found to be significant $(\mathrm{P}<0.01)$ for the trait (Table 6). This indicated that main stem thickness of genotypes ranked differently in different growing seasons. As seen in Table 6, the main stem 
Table 7- Correlation coefficients of forage yield components in the narbon vetch genotypes

Çizelge 7- Koca fiğ genotiplerinde ot verimi komponentleri arasindaki korelasyon katsayıları

\begin{tabular}{lccccccc}
\hline Characters & $F F Y$ & $D M Y$ & $D F$ & NPH & MSH & $M S N$ & $M S T$ \\
\hline Fresh forage yield (FFY) & - & & & & & & \\
Dry matter yield (DMY) & $0.725^{* *}$ & - & & & & \\
Days to 50\% flowering (DF) & $0.254^{*}$ & $-0.112^{\text {ns }}$ & - & & & & \\
Natural plant height (NPH) & $-0.182^{\text {ns }}$ & $-0.086^{\text {ns }}$ & $0.400^{* *}$ & - & & \\
Main stem height (MSH) & $-0.162^{\text {ns }}$ & $-0.091^{\text {ns }}$ & $0.519^{* *}$ & $0.457^{* *}$ & - & \\
Main stem numbers (MSN) & $0.220^{\text {ns }}$ & $0.133^{\text {ns }}$ & $-0.494^{* *}$ & $-0.514^{* *}$ & $-0.635^{* *}$ & - & \\
Main stem thickness (MST) & $0.077^{\text {ns }}$ & $0.002^{\text {ns }}$ & $-0.425^{* *}$ & $-0.396^{* *}$ & $-0.650^{* *}$ & $0.523^{* *}$ & - \\
\hline
\end{tabular}

Significant at *, $\mathrm{P} \leq 0.05 ; * *, \mathrm{P} \leq 0.01 ; \mathrm{ns}$, non-significant

thickness changed between 3.32 and $4.97 \mathrm{~mm}$ among the growing seasons and genotypes. Similarly, Van de Wouv et al (2003) reported that stem thickness varied among some thin-stemmed vetch species from 1.2 to $3.90 \mathrm{~mm}$.

Correlation coefficients among the examined traits are shown in Table 7. There were highly significant and positive correlation between fresh forage yield and dry matter yield $(\mathrm{r}=+0.725)$, although the correlation between fresh forage yield and days to $50 \%$ flowering were found statistically significant and positive $(\mathrm{r}=+0.254)$. Similar relations reported by Babat \& Anlarsal (2011) in common vetch (Vicia sativa L.) for the traits. Additionally, days to $50 \%$ flowering positively high significantly correlated with natural plant height $\left(\mathrm{r}=+0.400^{* *}\right)$, and main stem height $\left(r=+0.519^{* *}\right)$, Similarly, Sayar et al (2011) found high significant positive correlations between days to $50 \%$ flowering and both natural plant height $\left(\mathrm{r}=+0.462^{* *}\right)$ and main stem height $\left(\mathrm{r}=+0.373^{* *}\right)$ in forage pea (Pisum arvense L.). In contrast, the correlations for main stem numbers $\left(\mathrm{r}=-0.494^{* *}\right)$ and main stem thickness $\left(\mathrm{r}=-0.425^{* *}\right)$ with days to $50 \%$ flowering were found as negative and highly significant $(\mathrm{P}<0.01)$. On the other hand, natural plant height was positively significantly correlated with main stem height $\left(\mathrm{r}=0.457^{* *}\right)$, though it was negatively and significantly correlated with main stem numbers $(r=-0.514 * *)$ and main stem thickness $\left(\mathrm{r}=-0.396^{* *}\right)$. Despite negative and highly significant relationship between main stem thickness and main stem height $\left(\mathrm{r}=-0.650^{* *}\right)$, the relation between main stem thickness and main stem numbers $(\mathrm{r}=0.523 * *)$ was positively and highly significantly. Also; negative and significant correlation was found between main stem numbers and main stem height $\left(\mathrm{r}=-0.635^{* *}\right)$.

\section{Conclusions}

In conclusion, the promising narbon vetch lines showed great variation with respect to fresh forage yield, dry matter yield and other investigated components. According to three-year averages; five promising narbon vetch lines: IFVN 564-Sel 2379, IFVN 565-Sel 2380, IFVN 567-Sel 2382, IFVN 116-Sel 2461, IFVN 562-Sel 2470, were found more productive than the control cultivar, Tarman-2002, in terms of both fresh forage yield and dry matter yield. Hence, new narbon vetch cultivar or cultivars should be developed with the promising lines in order to be used for hay production in the Southeastern Anatolia region of Turkey.

\section{Acknowledgments}

This study was carried within the scope of "Southeastern Anatolia Region Forage Crops Research Project (TAGEM/TA/08/11/02/001)". 
The project was supported financially by General Directorate of Agricultural Research and Policy (TAGEM), Turkish Ministry of Food, Agriculture and Livestock. The authors would like to thank for their support.

\section{References}

Açıkgöz E, Turgut I \& Ekiz H (1986). Variation of seed yield and its compenents in Common Vetch under Different Conditions. XVI. International Grassland Congress, Nice-France, pp. 641-642

Açıkgöz E (2001). Forage Crops. Uludag Univ Publ no: 182, Bursa, Turkey, pp. 584

Albayrak S, M Güler \& Tongel M O (2004a). Effects of seed rates on forage production and hay quality of vetch-triticale mixtures. Asian Journal of Plant Science 3(6): 752-756

Albayrak S, Sevimay C S \& Tongel M O (2004b). The effects of inoculation with Rhizobium on forage yield and yield components of common vetch (Vicia sativa L.). Turkish Journal of Agriculture \& Forestry 28: 405-411

Altınok S (2002). The effects of different mixture of hairy vetch (Vicia villosa L.) and narbonne vetch (Vicia narbonensis L.) seeded with barley (Hordeum vulgare L.) on silage quality. Tarim Bilimleri Dergisi-Journal of Agricultural Sciences 8(3): 232-237

Altınok S \& Hakyemez H (2002). The effects on forage yields of different mixture rates of hairy vetch (Vicia villosa L.) and narbonne vetch (Vicia narbonensis L.) seeded with barley (Hordeum vulgare L.). Tarim Bilimleri Dergisi-Journal of Agricultural Sciences 8(1): 45-50

Anlarsal A E (1996). The effect of different cutting stages and seeding rates on forage and seed yields of narbonne vetch (Vicia narbonensis L.). Turkish Journal of Agriculture \& Forestry 20(6): 529-534

Avcioğlu R, Kavut Y T \& Okkaoğlu H (2009). Narbonne vetch (Vicia narbonensis L.). In Avcioglu, R. et al (eds). Forages-Legume Forages II. Publication of Turkish Ministry of Agricultural and Rural Affairs, Izmir, pp. 421-425

Babat S \& Anlarsal A E 2011. A study about the determination of yield and yield components of some common vetch (Vicia sativa L.) on ecological conditions of Diyarbakir. Journal of Science and Engineering of Çukurova University 26(3): 37-46
Ball D M, Collins M, Lacefield G D, Martin N P, Mertens D A, Olson K E, Putnam D H, Undersander D J \& Wolf M W (2001). Understanding forage quality. American Farm Bureau Federation Publication 1-01, Park Ridge, IL. Available at:http://forages. oregonstate.edu/resources/publications/foragequality. pdf (Access date: 15 November 2013)

Berger J D, Robertson, L D \& Cocks P S (2002). Genotype $\mathrm{x}$ environment interaction for yield and other plant attributes among undomesticated Mediterranean Vicia species. Euphytica 126: 421-435

Büyükburç U, İptaş S \& Yılmaz M (1994). A research on determination of annual some forage the legumes which will be adaptabtable in Tokat region. Gaziosmanpasa University Journal of Agriculture Faculty 11: 145-156

Büyükburç U \& İptaş S (2001). The yield and yield components of some narbon vetch (Vicia narbonensis L.) lines in Tokat ecological conditions. Turkish Journal of Agriculture and Forestry 25: 79-88

Ceçen S, Oten M \& Erdurmuş C (2005). Evaluation of some annual forage legumes as second crop in the coastal region of West Mediterranean Belt of Turkey. Akdeniz University Journal of Agriculture Faculty 18(3): 331-336.

Gramsh E S (1982). Variation in the quantitative characters of Vicia sativa L. Plant Breeding Absract 52(5)

Fırıncıoğlu H K, Unal S, Pank Z \& Beniwal S P S (2012). Growth and development of narbon vetch (Vicia narbonensis L.) genotypes in the semi-arid central Turkey. Spanish Journal of Agricultural Research 10(2): 430-442

Iptaş S, Büyükburç U \& Yılmaz M (1996). A research on determining the yield and adaptable of narbon vetch (Vicia narbonensis L.) lines in Tokat conditions. Turkey 3rd Pasture-Meadow and Forage Crops Congress, 17-19 June, Erzurum-Turkey, pp. 301-307

Iptaş S \& Karadağ Y (2009). Determination of the yield and yield components of narbon vetch (Vicia narbonensis L.) lines grown in spring. 1st International Symposium on Sustainable Development, June 9-10 2009, Sarajevo, pp. 83-88

Karadağ Y \& Buyukburç U (2004). Effect of Different Seed Ratios on forage and Seed Yield of Some Common Vetch Cultivars Under Tokat-Kazova Conditions. Tarim Bilimleri Dergisi-Journal of Agricultural Sciences 10(2): 149-157 
Lindsey R \& Reynold C (2003). A modern agricultural revolution in Fertile Cresent. (http://earthobservatory. nasa.gov/Features/Harran Plains)

Larbi A, Abd El-Moneim A M, Nakkul H, Jammal B \& Hassan S (2010). Intra-species variations in yield and quality determinants in Vicia species: 2. Narbon vetch (Vicia narbonensis L.). Animal Feed Science \& Technology 162: 20-27

Nizam I, Orak A, Kamburoglu I, Cubuk M G \& Moralar E (2011). Yield potentials of narbonne vetch (Vicia narbonensis L.) genotypes in different environmental conditions. Journal offood Agriculture \& Environment 9(1): $314-318$

Rahmati T, Azarfar A, Mahdavi A, Khademi K, Fatahnia F, Shaikhahmadi B \& Darabighane B (2012). Chemical composition and forage yield of three Vicia varieties (Vicia spp.) at full blooming stage. Italian Journal of Animal Science 11: e57: 309-311

SAS Institute (2002). JMP Statistics. Cary, NC, USA: SAS Institute, Inc. pp.707

Sabancı C O, Eginlioğlu G \& Ozpinar H (1996). A study on adaptations of narbon vetch (Vicia narbonensis L.) and grasspea (Lathyrus sativus L.). Turkey 3rd Pasture-Meadow and Forage Crops Congress, 17-19 June, Erzurum, Turkey, pp. 287-292

Sabancı C O, Özpınar H \& Eginlioğlu G (1998). Adaptations of forage crops to Menemen Conditions I. Narbon vetch (Vicia narbonensis L.). Anadolu Journal of AARI. 8(2): 42 - 50

Sayar M S, Anlarsal A E \& Basbağ M (2010). Current situation, problems and solutions for cultivation of forage crops in the Southeastern Anatolian Region. Harran University Journal of Agriculture Faculty 14(2): 59-67

Sayar M S (2011). Some Important Forage Crops Species in Pasture and Meadow Spaces of Southeastern Anatolia Region. Publication of GAP International Agricultural Research and Training Center (GAP IARTC) Diyarbakir, Turkey, pp. 53

Sayar M S, Anlarsal A E Basbağ M \& Açıkgöz E (2011). Determination of forage yield, its affecting components and relationships among traits of some forage pea (Pisum arvense L.) genotypes in Hazro ecological conditions. Turkey IX. Field Crops Congress, 12-15 September 2011, Bursa, Turkey, 3: 1716-1721

Steel G D \& Torrie J H (1960). Principles and procedures of statistics with special reference to biological sciences. New York; McGraw-Hill

Tan M, Koç A, Dumlu Gül Z, Elkoca E \& Gul I. 2013. Determination of dry matter yield and yield components of local forage pea (Pisum sativum ssp. arvense L.) ecotypes. Tarim Bilimleri Dergisi-Journal of Agricultural Science 19(4): 289-296

TIRTAFLS (2001). Technical Instruction for Registration Trials in Annual Forage Legumes Species. Publication of Seed Registration and Certification Centre, Ankara, Turkey, pp.36

TMF (2011). Diyarbakır Regional Directorate of Meteorology records, Turkish Meteorological Forecast of Turkey

Türk M, Albayrak S and Yüksel O (2007.) Effects of phosphorus fertilisation and harvesting stages on forage yield and quality of narbon vetch. New Zealand Journal of Agricultural Research 50: 457-462

Uzunmehmetoğlu B \& Kendir H (2006). Effects of winter and spring sowings on grain yields of narbon vetch (Vicia narbonensis L.). Tarim Bilimleri DergisiJournal of Agricultural Sciences 12(3):294-300

Van De Wouw M, Maxted N \& Ford-Lyod B V (2003). Agromorphological characterisation of common vetch and its close relatives. Euphytica 130: 281-292

Y1lmaz S (2008). Effects of increased phosphorus rates and plant densities on yield and yield-related traits of narbon vetch lines. Turkish Journal of Agriculture \& Forestry 32: 49-56

Yolcu H \& Tan M. 2008. General view to Turkey forage crops cultivation. Tarim Bilimleri Dergisi-Journal of Agricultural Sciences 14(3): 313-312

Yücel C, Hızlı H, Firincioğlu H K, Cil A \& Anlarsal A E (2009). Forage yield stability of common vetch (Vicia sativa L.) genotypes in the Cukurova and GAP Regions of Turkey. Turkish Journal of Agriculture \& Forestry 33: 119-125 